\title{
A Retrospective Evaluation on Prostitution Policy in Indonesia
}

\author{
Mohammad Suud \\ Faculty of Social and Political Sciences, Wijaya Kusuma Surabaya University \\ XXV/54 Dukuh Kupang Street, Surabaya 60225, Indonesia
}

\begin{abstract}
This paper presents a retrospective evaluation of prostitution policy in Indonesia, particularly in the last ten years of the period of the New Order Regime. Based on the secondary data, a retrospective analysis, in the frame of rationality and coherence, could give reliable and valid information to the prostitution policy and its results. In dealing with the prostitutes, the government tends to act unjustly, while the implication of the Indonesian Criminal Code as one of the national law conceals discrimination. The spirit of the law saves a moral weakness to endorse the creation of a good life for Indonesian having Pancasila as the way of life. Linked to the regulation of prostitution, the governmental efforts tend to be instant and frontal to tackle the prostitutes' matters. Because of the government ignored historical and substantial views, the governmental intervention in their matter brought more problems than solutions. The inconsistency of the local governments in managing the localization of prostitutes has compounded the problems. The governmental policy could not grasp the goals: rehabilitation and resocialization. The policy has strengthened the institutionalization of prostitute-pimp relations. The government has secretly become an institution serving pimps.
\end{abstract}

Keywords: policy, evaluation, prostitution.

DOI: $10.7176 /$ PPAR/9-12-02

Publication date: December $31^{\text {st }} 2019$

\section{Introduction}

\subsection{Background of the Research}

The subject of this research is adult female prostitution existing in Indonesia. This is based on the reason that female prostitution is a more endemic phenomenon than male prostitution. What specifically investigated as prostitution here is the system of localized prostitution complexes that are well known as 'lokalisasi' in Indonesia. This research try to unfold the effectiveness of the policy.

According to the Constitution of 1945, Article 27, "Every citizen has the right to work and live in human dignity" (MPR RI, 2012). ${ }^{1}$ This means that women and men have equal rights to work and live, and hence having a profession is an entitlement in the Indonesian context. The Constitution values those of being worked for every citizen. Because the Indonesian acknowledges the balance between rights and duties, the Indonesian must always try to obtain any decent profession. As a responsible institution to create job opportunities, the government must pay serious attention to this issue. The government should create good job opportunities or an adequate work environment for its peoples before the government asks for its citizens to operate decent professions. It is important to look at the primary role of the Indonesian government in creating employment opportunities with economic growth reached.

"According to the 1980 Population Census, the Indonesian workforce increased averagely by $2.7 \%$ per year. The 1990 population census revealed that the growth of the workforce amounted to 3.0\% per year. From 1980 until 1990, the number of workforces needing employment opportunities was almost 21.5 million persons, and increased to 85.8 million in the first year Repelita VI (1994/95), while the active workers until 1994 reached 82.9 million" (Soedarjanto, 1996).

Unfortunately, there is no clarification about why the number of workforces could be quadruple. Although the figures of active workers do not include prostitutes (Hull et al., 1997), it is clear that there is a great progress of the Indonesian government in creating job opportunities for its citizens. 2.9 million people are, however, still enough to supply a vast number of prostitutes, if sheer unemployment is a cause of prostitution. Besides that, as long as the government cannot yet create better job opportunities than prostitution, so becoming 'sex worker' constitutes an exciting alternative for some women and sometimes for men.

Concerning the issue of 'human investment', it is important to pay close attention to the participation of people, particularly the active participation of women. The role of the latter group tends to be ignored or late in Indonesian development. The government has formally paid attention to the group since Repelita IV through creating State Ministry for Women Roles, that it is well known as Deputy Ministry of Women Affairs in advance. This notion was influenced by 'social development' thought as a result of the International Conference of Social Welfare conducted by the Pre-Conference Working Party (PCWP) in Manila in 1971. Participation of women became more active and real in development after United Nations prevailed in the International Year for Women in the year. PCWP formulates social development as entire development aspects that link with social relations,

\footnotetext{
${ }^{1}$ The article is translated in English by author
} 
social systems, and values. Social development pays attention to the balance of human life to improve their social conditions. Social development is an effort to improve social life both at microstructure levels as a family and at macrostructure levels as a society (Sumarnonugroho, 1991).

\subsection{Statement of the Research Problem}

Generally, views on prostitution problems in Indonesia are divided into three interest groups. First are those who want prostitution to disappear from Indonesian society. Second are those who want the sex industry to be regulated and reformed effectively. Two strands of the problem derive from respectively these two different views: the 'moralist group' and 'pragmatist group'. There is a third group that asks for a clear and consistent attitude from the government towards the existence of prostitution (Hull et al., 1997).

The views of the two first groups showed by Hull et al. are essentially similar to the two first views stated by Truong. She shows three opposing views as follows: the moral view, the institutional view, and the women's social condition view (Truong, 1986).

One policy made by the government is the localized prostitution complexes well known as 'lokalisasi'. 'Lokalisasi' is "prostitution complexes that are managed based on regulations issued by local governments" (Hull et al., 1997). Such prostitution complexes are legalized and approved by the government. There are three indications to recognize whether a prostitution complex is legal or not. First, the existence of the complex is supported by regulations issued by local governments. Second, prostitutes existing in the complex acquire rehabilitation and resocialization programs. Third, the Municipal Social Welfare Office controls prostitutes existing in the complex. Otherwise, prostitution complexes that rise without agreement from local governments are illegal. Such prostitution complexes have no relation to rehabilitation programs undertaken by the government.

Prostitution continues in the system, generates 'legal income' for local governments and illegal income for the police, satisfies clients and provides the prostitutes with income; but the prostitutes have the chance to prepare for an alternative life, and the profession remains not officially endorsed. This is a compromise aimed to satisfy some interest groups.

According to the statistics data, the number of registered prostitutes in Indonesia increases year by year. It was 71.000 excluding unregistered free-lance sex workers and other workers who disguisedly offer sex services for their customers (Hull et al., 1997). Therefore, there is a real need to evaluate the prostitution policy implementing in Indonesia, especially in the last 10 years of the period of the New Order Regime.

\subsection{Formulation of the Research Problem}

To fulfill the above-mentioned need, we are aware that prostitution is a multidimensional phenomenon. One dimension of the phenomenon is politics. For that reason, this research covers the following question: What is the prostitution policy implementing in Indonesia and what are its results?

This research is to attain the two following goals: to know and understand the prostitution policy implementing in Indonesia and its results.

\subsection{Method of the Research}

Scope of the Research. This research highlights the past situation of prostitution in Indonesia, particularly Jakarta. This is based on reasons that the city is a metropolitan area, the largest in the country. Many prostitutes exist there in both a legal complex (Kramat Tunggak) and illegal ones (Cilincing, Angke, Kalijodo, Jalan Gajahmada, etc.). Interestingly, the majority of the inhabitants are practicing Moslems.

Retrospective Evaluation. To answer the question of this research, I use a formal evaluation approach, specifically a retrospective evaluation (Dunn, 2018). In terms of time, the retrospective analysis is limited to the last 10 years of the period of the New Order Regime, i.e. 1988-1998. This is based on reasons: the regime had a long experience in undertaking National Development, and the government in that time had a more concrete policy on prostitution relatively than the predecessor and the successor. But some relevant information after the period, i.e. 1999 , is also discussed.

Data Sources of the Research. This research uses secondary data. I collected the needed data from literature, document, statistics, journal, magazines, and mass media prepared at Library of Wijaya Kusuma Surabaya University, a private collection, and online sources.

\subsection{Organization of the Paper}

This paper will be organized as follows. Section one has been introduction consisting of background the research, statement of the research problem, formulation of the research problem, and method of the research. Section two examines relevant definitions and theories to establish an analytical framework for answering the research questions. Section three describes the prostitution policy in Indonesia and its results. This study is closed with a conclusion as a summary of its main arguments and some remarks. 


\section{Analytical Framework}

\subsection{Definition and Sector of Prostitution}

According to the Encyclopaedia Britannica (1975), prostitution might be defined as 'the exchange of money or valuable materials in return for sexual activity and the relatively indiscriminate availability of such a transaction to individuals other than spouses or friends.' It can thus be characterized by three major elements: payment, promiscuity, and emotional indifference. For this research, it will be adequate. This consideration refers to the importance of the element of payment in prostitution. As Scambler says, "Prostitution is taken to mean the exchange of money for sex - use value for exchange value..." (1997). As a form of social interaction, prostitution links and separates at a time between men and women with a different interest - the temporary relationship between sex and money - and it can repeatedly occur (Simmel, 1971). Davis emphasizes, "since some form of payment is found in social arrangements such as marriage and courtship, the element of promiscuity must be retained in the definition to differentiate prostitution from other types of relationships between sexes" (in Truong, 1988).

On Rowbotham's definition, "prostitution is seen as an expression of the 'cultural hegemony' of men over women" (in Truong, 1988). Based on Rowbotham's view, Barry elucidates that "under male cultural hegemony women form a vulnerable social group, and that this vulnerability provides ample opportunity for men to sexually abuse and exploit them" (in Truong, 1988).

From these definitions, two main issues emerge. First, material gains can be in the form of money and/or gifts and social mobility for both individuals and groups. Second, the act of prostitution must be seen both at the level of individual motive and concerning the structure of the social relationship between men and women and the class structure of society (Truong, 1986).

Referring to Black's delimitation of sector, prostitution might be seen as a tertiary sector or service sector (1977). The underground nature of the sex sector makes it very difficult to determine its actual size and economic significance. Lim estimates that the contribution of the sex sector is between 2 percent and 14 percent of gross domestic product in countries such as Indonesia, Malaysia, the Philippines and Thailand (1998).

Lim says that prostitution has economic components relating to economic progress, modernization and a growing sense of materialism, and social components relating to unequal relations between men and women (1998).

\subsection{The Rationality and Coherence of Policy}

The Rationality of Policy. The theory of society - state relation will be relevant to analyze a prostitution phenomenon, particularly in this research. But, "the traditional dichotomy between state and civil society remains problematic when investigating prostitution. We need to make allowances for flexible boundaries, dichotomies, and dialectical relationships between state and society, as institutions within and outside the state exercise and legitimate their power. We do well to remember that prostitution is a dependent institution, reflective of gender, economic and political stratification orders, and of transforming family relations" (Davis, 1993).

Prostitution is explored as a multidimensional phenomenon: "as a social crisis embracing concepts of both danger and opportunity, as a complex occupational structure, and as a distinct politic" (Davis, 1993). The complexity of this prostitution problem deserves attention from policymakers because a policy has to be problem(s) resolution oriented (Laswell, 1968).

The notion developed here is to justify the relevance of rationality and coherence of policy on prostitution. To understand the rationality of policy on prostitution, we must appreciate the underlying values and who are the involved people. According to the Oxford Dictionary of Philosophy, there are two kinds of views on the status of value: as subjective (a protected personal choice) and objective (a guided and corrected personal choice) (Blackburn, 1996). The former issue leads us to assess the ideology (Heineman et al, 1990) that underlies the policy goals while the latter issue guides us to take into account stakeholders (Nutt and Backoff, 1992) who involve or must be involved in the policy path, particularly in a policy formulation.

The Coherence of Policy. To know how good policy is, we need to test the belief for truth in the light of other beliefs, including perceptual belief, and then we need to step inside our belief system to anticipate how well it is doing in terms of coherence with the reality. According to the Oxford Dictionary of Philosophy, "A system is consistent if it does not yield both a formula and its negation..."(Blackburn, 1996). We have to be consistent with the body of truth. In looking for the basis of consistency, we must know upon what the structure of our belief is constructed in time and place dimensions.

The term 'social entitlement' deserves attention from the government to reduce the sense of uncertainty, particularly for prostitutes to grasp their freedom and rights. Concerning the term, Dixon-Mueller notes that this term stands on the two following views. First is that every people has individual rights that cannot be separated from himself or herself. Second is that society and state should ensure not only freedom and opportunity for the citizen but also the capacity of the citizen to obtain what freedom and rights of theirs (in Adrina, et al., 1998). 
The political will of the government, as a regulator to resolve the prostitution problem, must be effective and consistent and fill a need of stakeholders, particularly the prostitutes. The prostitutes are necessary to involve in resolution of their problem, when and where they will meet that condition. It is very important so that we don't face the anomalous situation of having strongly worded policies and weak actions.

Prostitution might not only be viewed as a moral issue but also within the perspective of the social entitlement that should be guaranteed by government and society alike. The prevailing morality and perception of prostitution that describes prostitutes as women who deviate from standard codes of sexual conduct conceal many aspects of social transformation affecting women as a group. However,

"Although many women choose prostitution as a strategy of survival for themselves as individuals, and for their family, it should be kept in mind that viewing the act of prostitution as a calculated rational choice is not sufficient for a full understanding of the phenomenon. Such a view tends to ignore the economic system underlying the institution in which individual and collective interests are grounded" (ESCAP, 1985).

Now let us clarify the dimensions of time and place as basis of consistency of policy on prostitution. Time is to focus more on how long before the government can create better job opportunities than prostitution or provide adequate social security than the chance in which prostitutes have to prepare for an alternative life. The better job opportunities are an amount of other decent works that can be chosen or obtained by prostitutes or exprostitutes instead of prostitution.

Place is to focus more on places where prostitutes can maintain their welfare in the social context than their segregation or isolation from society at large. The view developed here is that attempts to segregate or isolate the prostitutes from society at large will be in vain as long as the government itself cannot meet its obligations yet: creating a better job opportunity rather than prostitution or providing the social security rather than prostitution. The government must take into consideration the prostitutes' involvement to embody their well-being in time and place dimensions rather than on merely the return of prostitutes into their families or society.

\section{The Policy of Prostitution}

\subsection{The History and Trends}

The existence of the commercialization of sex in the feudal period has underlain the growth of prostitution existing today. That condition could be seen through values treating women like things. Jones et al. call it 'the commoditization of women' (in Lim, 1998). The treatment of women as commodities happened not only in Java but also in Bali (Hull et al., 1997).

The more organized forms of prostitution grew fast during the Dutch colonial period. In 1650, the colonial government established 'house of correction for women' to rehabilitate prostitutes and protect public order. In 1852, the colonial government introduced a new regulation agreeing to the commercial sex industry, including a series of regulations to avoid its harmful consequences. The 'public women' were suggested to operate in brothels. In 1858, another regulation clarified that the 1852 Act was not to be interpreted as having legitimized brothels as commercial institutions but as places of medical consultation to limit the harmful effect of prostitution (Hull et al., 1997). The problem is that society and prostitutes may have different perceptions rather than the government has.

Two decades later, the central government shifted responsibility for controlling brothels to local governments. For example, in 1875, the Batavian government (Jakarta now) promulgated regulation of medical checkups of prostitutes where medical workers were responsible to control the health of prostitutes (Hull et al., 1997).

The legal framework made in 1852 might be compatible with laws that prevailed in the Netherlands. But it was still inadequate seen from the side of prostitutes' rights, equalities or detection of dangerous infected diseases.

The sex commercialization in Indonesia was further entrenched during the Japanese occupation between 1941 and 1945. Women who were already working as prostitutes were rounded up, and after health checks, some were allocated to brothels to serve the Japanese soldiers while others continued to operate as before. Many adolescents and schoolgirls were brought from their original towns or villages for better education and life in Tokyo and other cities in Indonesia. But these girls became sex slaves for the Japanese soldiers and officers (Tempo, 1992).

In the colonial period, prostitution was condemned by society based on two reasons: public health and public morality (Hull et al., 1997). This view more emphasizes dangers faced by society particularly men while less pay attention dangers faced by women or women's interests. Many persons already accept such views although its worth for human beings is fundamentally questionable.

\subsection{The Legislation and Regulation of Prostitution}

The Legislation of Prostitution. John et al. stipulated that up to the time there is no law in Indonesia prohibiting explicitly the sale of sexual services. The Indonesian Criminal Code just prohibits those who help and facilitate 
illegal sexual services. The Criminal Code also prohibits the trading of women and under-age boys. The relevant articles are as follows ( in Lim, 1998).

Article 296: "Those whose actions or attitudes intentionally lead to or facilitate illegally sexual activities with other people will be given a penalty of one year and four months imprisonment or a fine of Rp. 15,000 (US\$7)."

Article 297: "Trade in women or under-age males will incur a maximum penalty of six years imprisonment."

Article 506: "Whoever as mucikari (pimp) derives profits from prostitution of women, will incur a maximum penalty of three months imprisonment."

There are also difficulties to accuse a married person being adulterous by using Articles 284-288 of the Code. "First, it will be difficult to prove that the prostitutes know their client is married. Second, ...it requires a formal complaint from the client's wife and evidence of a breakdown of the marriage as a result of the adultery..." (Hull et al., 1997). Besides that, it must be kept in mind that women who work in brothels are usually unmarried.

"In Indonesian society, law extends beyond the legislative provisions of the government and includes both religious laws and customary regulations. While these generally are not opened to prosecution in state courts, they do shape community norms and attitudes, and modify the way civil laws are carried out in practice" (Hull et al., 1997).

Mu'thi points out the difference between the meaning of adultery in the Criminal Code and the Islamic law (Syariah). In the former, a married person only can commit to adultery, because the purpose of the law is to support monogamous relationships rather than to pass judgments on premarital sexual behavior. In the latter, all premarital sexual relations are regarded as adulterous. A polygamous man is not committing adultery by having sexual relations with more than one legal wife, but both man and women can only have sexual relations with their legal spouse. The implication is that a female prostitute cannot be prosecuted for adultery under the Criminal Code as long as she is not married, but her actions remain will be condemned as sin under the religious law. Mu'thi questions the moral basis for the Code, which is a legacy of the colonial period of limited relevance to the majority of Indonesians who are practicing Muslims (1965).

This is an unfair treatment that the pimp can be prosecuted, but the person who has sexual services for money is free from restraint. This is a challenge for policy-makers to seek an adequate assumption as a basis to amend the Code (Suud, 2015).

The Regulation of Prostitution. Because the prohibition of direct commercial sex services does not exist in national law, the regulation of the sex sector tends to be based on each provincial or sub-district government regulation. This is in part important to let different localities decide differently for developing decentralization or district autonomy. However, it is also important to have an adequate national policy, as a basis of our commitment to humanity in dealing with this phenomenon.

One important governmental policy is the rehabilitation of prostitutes in the official prostitution complexes. The legalization of prostitution seems based on the reasonable assumption that prostitution cannot be stamped out, and that it needs to be controlled in the interests of public safety and order. Such 'lokalisasi' are usually under the control of the Municipal Social Welfare Office. However, illegal prostitution complexes also arise, which have no direct relation to the rehabilitation program directed by the Social Office (Hull et al., 1997).

A first legal localized prostitution complex in Jakarta arose in 1970s when Ali Sadikin was Governor of Jakarta. The biggest and only 'lokalisasi' is well known as Kramat Tunggak, which aimed at gathering and rehabilitating prostitutes. This policy was based on the Letter of Decision of Governor Number Ca.7/1/13/70, Ca.7/39/71, and Ca. 7/1/32 (Sedyaningsih-Mamahit, 1999). The rehabilitation goals for prostitutes will be reached through education, skills training, and mental and social guidance undertaken by Rehabilitation Institution or 'Panti Rehabilitasi'. This is to help prostitutes leave the complex to work in other professions (Umiyono, et al., 1992).

Prostitutes in the complex are only temporary while undergoing rehabilitation and resocialization. The minimum age to enter the complex is 17 years. They are only permitted to live in the complex for a maximum of five years or until reaching the age of 35 (Umiyono et al., 1992). Pimps are also subject to this regulation, in where they are only permitted to operate one brothel for five years and a three years maximal extension (Sedyaningsih-Mamahit, 1999).

The central government Department of Social Affairs runs 22 rehabilitation centers nationwide. Such rehabilitation must be differentiated with the Municipal Social Welfare Office's rehabilitation. With central government funding, the Department of Social Affairs educates prostitutes in the Rehabilitation Institution for a maximum of six months before they are given back to their original region. During the rehabilitation period, they are prohibited to operate sexual services for clients. With more regular and stricter education, this effort can be considered as having the serious objectives of retraining the prostitutes for working in other sectors of the economy as well as encouraging them to leave commercial sex work permanently. However, many of the 
women in the rehabilitation center are 'sickly prostitutes' who are rounded up in police raids on illegal prostitution complexes or hotels and are strongly encouraged to join the program (Hull et al., 1997). It means that they ever followed a rehabilitation program in a rehabilitation center. After they go back into society they don't get appropriate work. For surviving, they operate sexual services again in illegal prostitution complexes.

In contrast, with limited local government funding, the Municipal Social Welfare Office runs a legalized prostitution complex, Kramat Tunggak for instance, that also educates the prostitutes, but does not prohibit them to give sexual services to their clients. This center claimed that many prostitutes left the complex and went back to normal life (Hull et al., 1997). Sedyaningsih-Mamahit noted from 1972 to 1993 the Kramat Tunggak's rehabilitation center sent 11,624 prostitutes back to normal life, 2,795 of them into marriages, 6,229 to their families and another 1,420 to jobs (1999). However, Murray stated that this was not valid because most of the prostitutes who left the localized prostitution complex would re-enter or moved to other complexes in the same city or the other ones (1991).

Results of the Policy. Kramat Tunggak, like other local prostitution complexes, is a prostitution complex operated upon the basis of the brothel where people who have appropriate resources can operate brothel(s) with some prostitutes in the complex. One key requirement to stay in the complex is that the prostitutes and pimps have operated similar work outside Kramat Tunggak or in illegal prostitution complexes (Sedyaningsih-Mamahit, 1999). So, Kramat Tunggak and other similar prostitution complexes are a transition place for prostitutes and pimps to change their profession to other decent professions. What are the results of this policy?

There are four results of the policy. First, although the regulations setting up the complexes mentioned specific areas from which prostitutes were to be moved and where the practice was to be subsequently disallowed, prostitution in a variety of forms has continued to flourish in areas outside the official complexes, for instance, Cilincing, Binaria Ancol, Kalibaru, North Koja, Pejagalan, Pademangan and Penjaringan in Jakarta (Hull et al., 1997). The local government endorsed the first two unofficial prostitution complexes which operate close to Kramat Tunggak, while the last five unofficial prostitution complexes which exist in areas of North Jakarta commercial sex practices were prohibited. Suara Karya newspaper even reported that in West Jakarta, such as in Angke and Jelambar Baru, areas that should be closed for prostitution since 1992 have become the center of commercial sex practices of about 500 prostitutes operated at huts along the Kalijodo riverbank (1992). It means in part that the effectiveness of the localization of prostitutes is linked with the prospect of the economic values of the place because every place has a different value economically (utility of place). Prostitution complexes placed in an economic zone will have a considerable prospect of success in concentrating the prostitutes or the complexes. Hull et al. (1997) note that a part of woman labors having an interest in the sex industry after hours have a motivation of seeking additional income fast. Some registered prostitutes even recognize that they seek tacitly additional income outside the legal prostitution complexes.

Second, the programs have succeeded in only a very limited extent in returning prostitutes to society in the sense of ceasing the practice of prostitution (Hull et al., 1997). This is not surprising given that the earnings available with prostitution are better than alternative occupations opened to poorly educated women. Prostitutes' per month net income at Kramat Tunggak varied. $2 \%$ of prostitutes recognized having income less than or equivalent to Rp.100, 000; 56\% of them had income more than Rp.100, 000 to Rp.500. 000; 42\% of them had income more than Rp.500, 000. In comparison with the wages of factory laborers or housemaids earning a living less than Rp.100, 000 per month in the same year, it is not surprising if Kramat Tunggak has always 'new faces' (Sedyaningsih-Mamahit, 1999). Moreover, there has been considerable displacement of women from agricultural activities (Manning, 1988).

Third, the officially approved pimps find not only profit to run a brothel(s) in the legalized prostitution complex but also safety from prosecution (Hull et al., 1997:36). The earnings of pimps at Kramat Tunggak are around Rp.100, 000 to Rp.250, 000 per day. It means that, if they work 25 days per month, their incomes are about Rp.2, 500,000 to Rp.6, 250,000 per month (Umiyono, 1992).

Fourth, local government authorities gain substantial revenue from prostitution complexes. Though the stated aim of the complex is to rehabilitate the prostitutes, where this is to be successfully achieved, the lucrative source of revenue would dry up. Hotman Siahaan notes in Sinar magazine the profits derived from the localized prostitution complexes are not treated as officially stated income because to do so will expose the transaction to investigations by the legislative branch. This will expose the contradictory nature of the arrangement (1994). It looks like that the local governments become tacitly brothel institution. The stated aim of the localization policy has been dragged to become 'quasi-localization policy'. According to the Article 506 of the criminal law, whoever as pimp to derive profits from prostitution of women will incur a maximum penalty of three months imprisonment, while the government becomes tacitly a pimp service institution.

Anyway, in 1996 the Jakarta authorities considered relocating Kramat Tunggak to another area because they viewed that the prostitution complex was not already separated from society at large. So it was not suitable in the ground of the harmony of the social environment. The Vice-Governor of Jakarta, RS Museno, even said that Kramat Tunggak disgraced Jakarta's reputation (Kompas, 1996). 
Based on the Governor's Decision Letter Number 6485/1998, in 1999 the Governor of Jakarta, Sutiyoso, closed Kramat Tunggak without the reason of relocating the prostitutes and pimps to another area. He just expected the prostitutes and pimps to switch to respected works. He did this activity with an assumption that the pimps have had enough capital to do respected jobs and the prostitutes have had enough skills to move to decent works because they have been long staying in the complex. One of the ironies of this action is that the legal prostitution complex is closed while Jakarta's illegal prostitution complexes, such as Kalijodo, Pela-pela, Rawawalang, Kramatjaya, Jalan Blimbing, Jalan Gajahmada, etc., persist in serving the commercial sex (Kompas, 1999).

\section{Conclusion}

As concluding notes, I wish to sum some main arguments and remarks up of the previous sections. The growth of prostitution in Indonesia moved from Javanese Kingdom period until the Old Order Regime and the New Order Regime. Commoditization of women was a dominant characteristic during the Javanese Kingdom period. Commercialization of sex services was a dominant characteristic during the Dutch and Japanese colonial with some sex slavery practices in the latter. During the periods, where unequal social and economic relationships between women and men exist, the existence of prostitutes as humans tended to be ignored. These circumstances must be kept in mind so that we are not trapped in an unhistorical view, and then we can avoid brutal or frontal actions to deal with the prostitution problem in the future.

The policy of prostitution in Indonesia during the last ten years of the New Order Regime tend to be ignored the historical contexts and the substance of the prostitution problem. Such an approach has driven the government to deal with the problem of prostitutes and prostitution in injustice. While the Indonesian Criminal Code is the only regulation for prostitution at the national level, the implication for pimps, prostitutes, and clients conceals discrimination. The spirit of the law has a moral weakness to create a good life for Indonesian having Pancasila.

The above-mentioned policy tends to view the prostitutes as an object rather than as a subject. Such an approach has driven the government to treat the prostitutes instantly and frontally. As long as the policy of prostitution is based on the unhistorical and unsubstantial views, the governmental intervention in prostitution would bear the problem rather than the solution. The inconsistencies of the local authorities in regulating and treating the legalized prostitution complexes have compounded the problems. The policy of localization could not reach the main goals: rehabilitation and resocialization. Instead, prostitution in various forms continues to grow outside the official complexes, including horizontal mobility of prostitutes; the policy tends to strengthen the institutionalization of the relation of prostitutes and pimps; the government becomes the institution of pimp services.

\section{References}

Adrina, et al. (1998) Hak-Hak Reproduksi Perempuan yang Terpasung. Jakarta: Pustaka Sinar Harapan, xi-xii. Black, John (1997) Dictionary of Economics. New York: Oxford University Press, 419.

Blackburn, Simon(1996) Dictionary of Philosophy. New York: Oxford University Press, 78; 390.

Bureau of Law Social Department (1983) Himpunan Peraturan Perundang-Undangan Kesejahteraan Social. Surabaya: Social Department.

Davis, Nanette J. (1993) 'Introduction. International Perspective on Female Prostitution', in Nanette J. Davis (ed.), Prostitution: An International Handbook on Trends, Problems, and Policies. London: Greenwood Press, 5-8.

Dunn, William N. (2018). Public Policy Analysis: An Integrated Approach (Sixth Edition). New York: Routledge, 333-336.

Encyclopaedia Britannica (1975) The New Encyclopaedia Brittanica. London: Helen Hemingway Benton, Publisher, 75.

ESCAP (1985) 'Report of the Workshop of Experts on Prevention and Rehabilitation Schemes for Young Women in Prostitution and Related Occupation, report represented at the Workshop, UN/ESCAP, Bangkok, 17-21 June, 5.

Heineman, Robert A., et al. (1997) The World of the Policy Analyst. New Jersey: Chatam House Publisher, Inc., 39.

Hull, Terence H. et al. (1997) Pelacuran di Indonesia. Sejarah dan Perkembangannya. Jakarta: PT. Pustaka Sinar Harapan, 1-6; 26-63; 109-118.

Kompas (1996) Kramattunggak Direncanakan Pindah, Memindahkan dan Mencari Lokasi Baru Bukan Hal Mudah, http://www.kompas.com (13 Mei 1996).

Kompas (1999) Kramat Tunggak Berhenti di Tengah Jalan, http://www.kompas.com (10 Desember 1999).

Laswell, Harold D. (1968) 'The Policy Sciences' in Encyclopedia of the Social Science. New York: McMillan/Free Press, 181. 
Lim, Lin Leam (1998) The Sex Sector. The Economic and Social Bases of Prostitution in Southeast Asia. Geneva: International Labour Office, 7-12; 29-57.

Manning, Christ (1988) The Green Revolution, Employment Economic Change in Rural Java: A Reassessment of Trends under the New Order. Singapore: Institute of Southeast Asian Study, 35.

MPR RI (2012) Panduan Pemasyarakatan Undang-Undang Dasar Negara Kesatuan Republik Indonesia Tahun 1945 dan Ketetapan Majelis Permusyawaratan Rakyat Republik Indonesia. Jakarta: Sekretariat Jenderal MPR RI, 175.

Mu’thi, Abdul (1965) 'Sedikit tentang Hukum Perzinahan’, Gema Islam, 4(79-80):13-16.

Murray, Alison J. (1991) No Money No Honey. Singapore: Oxford University Press, 106.

Nutt P C and R W Backoff (1992) Strategic Management of Public and Third Sector Organization. San Francisco: Jossey-Bass Publisher, 190.

Scambler, Graham and Annette Scambler (1997) Rethinking Prostitution. London: Routledge, 10.

Sedyaningsih-Mamahit, Endang R. (1999) Perempuan Perempuan Kramat Tunggak. Jakarta: Pustaka Sinar Harapan, 32-45.

Simmel, Georg. (1971) "Prostitution”. In Donald N. Levine (ed.), Georg Simmel: On Individuality and Social Form. Chicago: University of Chicago Press, 121-126.

Sinar (1994) Akan Muncul Hartono-Hartono Lain (25 Juli 1994), 23.

Soedarjanto, et al (1996) Indonesia 1996. An Official Handbook. Jakarta: Department of Information, 164.

Suara Karya (1992) Pelacuran Beroperasi di Sepanjang Tepian Kalijodo (13 Mei 1992).

Sumarnonugroho, T. (1991) Sistem Intervensi Kesejahteraan Sosial. Yogyakarta: PT. Prasetya Widya Pratama, 89.

Suud, Mohammad (2015). Appropriate Policy on Prostitution in Indonesia: A Strategy to Minimize Social Impacts in Society. Journal of Public Policy and Administration Research. Vol. 5, No. 10, 109.

Tempo (1992) Kelana, Pandir, Kisah Kadarwati yang Sebenarnya (25 July 1992), 17-18.

Truong, Thanh-Dam (1986) 'Virtue, Order, Health and Money: Towards A Comprehensive Perspective on Female Prostitution in ASIA', paper presented at the Workshop of Experts on Prevention and Rehabilitation Schemes for Young Women in Prostitution and Related Occupation. Institute of Social Studies, Bangkok, 17-21 June 1986, 2-6.

Truong, Thanh-Dam (1988) Sex, Money and Morality. The Political Economy of Prostitution and Tourism in South East Asia. London: Zed Books, 18-20.

Umiyono, et al., (1992) Lokalisasi dan Hukum: Suatu Tinjauan Yuridis terhadap Praktek Bertahannya Pelacuran di DKI Jakarta. Jakarta: Badan Epidemologi National, Pusat Penelitian Kesehatan, Universitas Indonesia, 16-41. 